\title{
An efficient method for in vitro propagation of Alstroemeria pallida Graham rhizomes
}

Danilo Aros ${ }^{1 *}$, Marko Vásquez ${ }^{1}$, Constanza Rivas ${ }^{1}$, and Maria Loreto Prat ${ }^{1}$

\section{ABSTRACT}

Alstroemeria is a genus native to South America and commercially has commonly been propagated vegetatively by rhizome division, with low efficiency, high time consumption and a high risk of virus dissemination. In vitro propagation has several advantages, particularly in terms of efficiency and has been applied to the micropropagation of alstroemeria. This study aims to describe an efficient method for the in vitro propagation of Alstroemeria pallida Graham, a Chilean native species of high ornamental value. Concentrations of agar $(0.0$, 3.5 and $\left.7.0 \mathrm{~g} \mathrm{~L}^{-1}\right)$ and 6-benzylaminopurine (BAP) (0.0, $0.5,1.0$ and $2.0 \mathrm{mg} \mathrm{L}^{-1}$ ) were supplemented with MS culture medium to evaluate explant weight $(\mathrm{g})$, rhizome length $(\mathrm{cm})$, shoot length $(\mathrm{cm})$ and proliferation rate. The highest explant weight was observed in rhizomes grown in culture medium supplemented with $3.5 \mathrm{~g} \cdot \mathrm{L}^{-1}$ agar (3.79 $\mathrm{g}$ ), and treatments using $2.0 \mathrm{~g} \mathrm{~L}^{-1}$ BAP showed the highest weight increase $(3.33 \mathrm{~g})$ after $8 \mathrm{wk}$. The proliferation rate rose with increasing concentrations of $\mathrm{BAP}$, whereas low concentrations of BAP promoted longer shoots. An efficient method for in vitro propagation of A. pallida rhizomes was described, which could be useful for its conservation, domestication and further breeding.

Key words: Alstroemeria, cytokinins, agar, tissue culture and micropropagation.
${ }^{1}$ Universidad de Chile, Facultad de Ciencias Agronómicas, Santa Rosa 11315, La Pintana, Santiago, Chile.

*Corresponding author (daros@uchile.cl).

Received: 2 September 2016

Accepted: 19 January 2017

doi:10.4067/S0718-58392017000100012

\section{INTRODUCTION}

Alstroemeria belongs to the Alstroemeriaceae family and is native to South America, comprising 75 species (Bayer, 1987). Chile and Brazil are the main diversity centers with 33 and 39 native species, respectively (Muñoz and Moreira, 2003; Hofreiter and Rodríguez, 2006). Alstroemeria became very popular in the ornamental market both as cut flower and pot plant (Hoshino, 2008) due to the development of several varieties bred by techniques such as mutagenesis (Aros et al., 2012), polyploidization (Lu and Bridgen, 1997) and mainly interspecific hybridization (Bridgen et al., 2009). Propagation of alstroemeria has been commonly performed vegetatively by rhizome division, with low efficiency, high time consumption (Lin et al., 1997) and a high risk of virus dissemination, affecting yield during cultivation (Van Zaayen, 1995). In vitro propagation has been also considered to propagate alstroemeria since this technique has several advantages, particularly in terms of efficiency (Yousef et al., 2007; Pumisutapon et al., 2011; Seyyedyousefi et al., 2013; Hutchinson et al., 2014). Rhizome sections have been the most common explant used for the in vitro propagation of alstroemeria (Pumisutapon et al., 2012; Shahriari et al., 2012), although some experiments have also considered aerial explants such as stem (Kim et al., 2006), leaf (Nasri et al., 2013) and flower buds (Pedraza-Santos et al., 2006). In addition to the type of explant, characteristics of the culture medium are crucial to achieving successful micropropagation. In particular, the effect of the concentration of gelling agents (Ebrahim and Ibrahim, 2000; de Klerk and ter Brugge, 2010) and plant growth regulators (Cruz et al., 2003; Hamidoghli et al., 2007) have been widely studied in the micropropagation of alstroemeria and other species. Agar is the most common gelling agent and can influence the type of growth response of micropropagated plants. Cytokinins are a type of growth regulator related to cell division, shoot multiplication, and axillary bud proliferation (Kyte et al., 2013).

Most of the studies related to in vitro propagation of alstroemeria have been performed using commercial varieties (Khaleghi et al., 2008; Pumisutapon et al., 2012; Hutchinson et al., 2014) and hybrids (Nasri et al., 2013), but little is known about micropropagation of the wild species of this genus.

Alstroemeria pallida is native to Chile and shows a restricted distribution in the Andes Mountains between Los Andes (32 50 ' S), Region of Valparaíso, and Río Maipo (34¹0' S), Metropolitan Region, at an altitude between 1500 and 2800 m (Cavieres et al., 
1998). This species has high ornamental value given its pink flowers and compact and mounded plant habit, which are valuable traits for potted plants. Considering the importance of the conservation of native species and the benefits of in vitro culture, this study was aimed at developing an efficient method, using different concentrations of agar and cytokinins in the culture media for in vitro propagation of the wild species Alstroemeria pallida Graham.

\section{MATERIALS AND METHODS}

\section{Plant material}

Rhizomes of Alstroemeria pallida were obtained from the in vitro rescue of embryos collected in January 2014 in Farellones, Metropolitan Region, Chile, at an altitude of $2300 \mathrm{~m}$. Individuals selected for this study were clones produced by a single embryo in order to avoid possible effects of the genotype on the results.

\section{In vitro propagation}

Twelve treatments resulting from the combination of three agar concentrations $\left(0.0,3.5\right.$ and $\left.7.0 \mathrm{~g} \mathrm{~L}^{-1}\right)$ and four cytokinin concentrations $\left(0.0,0.5,1.0\right.$ and $2.0 \mathrm{mg} \mathrm{L}^{-1}$ 6-benzylaminopurine [BAP]) were set in a completely randomized factorial design. Eight replicates per treatment were performed and the experimental unit consisted of one rhizome section of about $1.0 \mathrm{~cm}$ with one shoot, cultured in a $200 \mathrm{~mL}$ glass jar containing $42 \mathrm{~mL}$ MS medium (Murashige and Skoog, 1962), $30 \mathrm{~g} \mathrm{~L}^{-1}$ sucrose, adjusting the $\mathrm{pH}$ to 5.8. A cotton layer in the bottom was used as support for treatments grown with liquid medium $\left(0.0 \mathrm{~g} \mathrm{~L}^{-1}\right.$ agar). The rhizome sections were cultured under controlled conditions at $23{ }^{\circ} \mathrm{C}$ and a photoperiod of 16:8 h (regime provided by fluorescent tubes with density photosynthetic photon flux of $900 \mu \mathrm{mol}$ photons $\mathrm{m}^{-2} \mathrm{~s}^{-1}$ ).

At week 4 the explants were transferred to fresh glass jars, keeping the same conditions of the culture medium previously described for each treatment.

\section{Evaluations}

Evaluations were performed after 0, 4 and 8 wk and considered explant weight $(\mathrm{g})$ and rhizome length $(\mathrm{cm})$. At week 8, shoot length and number of regenerated shoots per explant were evaluated. The proliferation rate was calculated as the ratio between the final and the initial number of explants obtained. Furthermore, photographs of the explants after 8 wk were taken using a Nikon D3000 10 Mpx Black (Nikon Co., Tokyo, Japan).

\section{Statistical analysis}

Data from explant weight, rhizome length and proliferation rate were subjected to an ANOVA using the MINITAB software (Minitab Inc., State College, Pennsylvania, USA). Means were compared using Tukey's honest significant difference (HSD) test for multiple pair-wise comparisons with a significance level of 0.05 .

\section{RESULTS}

\section{Effect of agar on explant weight and rhizome length}

The statistical analysis showed no interaction between the effects of agar and BAP on the evaluations of explant weight and length; therefore, they were independently analyzed using an ANOVA.

The highest explant weight was observed in rhizomes grown in culture medium supplemented with $3.5 \mathrm{~g} \mathrm{~L}^{-1}$ after $4 \mathrm{wk}(2.81 \mathrm{~g})$ and after $8 \mathrm{wk}(3.79 \mathrm{~g})$, showing in both cases significant differences to the other treatments. After $8 \mathrm{wk}$ the weight gained using 0.0 and $7.0 \mathrm{~g} \mathrm{~L}^{-1}$ agar was 1.93 and $1.78 \mathrm{~g}$, respectively, significantly lower than the weight gained using $3.5 \mathrm{~L}^{-1}$ agar (2.73 g) (Table 1). Significant differences in terms of rhizome length were not observed between the different concentrations of agar applied. Thus after 8 wk the rhizome length reached values between 1.77 $\left(3.5 \mathrm{~L}^{-1}\right)$ and $1.95 \mathrm{~cm}\left(7.0 \mathrm{~L}^{-1}\right)$ (Table 1).

\section{Effect of BAP on explant weight and rhizome length}

After 4 wk of in vitro culture, rhizomes grown in a free BAP culture medium presented the lowest explant weight $(2.10 \mathrm{~g})$, showing significant differences with treatments using $1.0(2.61 \mathrm{~g})$ and $2.0 \mathrm{mg} \mathrm{L}^{-1}(2.64 \mathrm{~g})$ BAP. After $8 \mathrm{wk}$, rhizomes grown in a culture medium supplemented with 2.0 $\mathrm{g} \mathrm{L}^{-1}$ expressed the highest weight increase (3.33 g), and this treatment was significantly different to other concentrations of BAP applied (Table 2). Rhizome length showed no differences after $4 \mathrm{wk}$ between treatments using different BAP concentrations. However, after 8 wk rhizomes grown in culture media supplemented with 1.0 and $2.0 \mathrm{mg} \mathrm{L}^{-1} \mathrm{BAP}$ were significantly longer than the other treatments, showing 2.18 and $2.40 \mathrm{~cm}$, respectively (Table 2 ).

Table 1. Explant weight and rhizome length observed after 0 , 4 and 8 wk on Alstroemeria pallida rhizomes cultured in vitro under three different agar concentrations.

\begin{tabular}{|c|c|c|c|c|c|c|}
\hline \multirow[b]{2}{*}{$\begin{array}{c}\text { Agar } \\
\text { concentration }\end{array}$} & \multicolumn{2}{|c|}{$0 \mathrm{wk}$} & \multicolumn{2}{|c|}{$4 \mathrm{wk}$} & \multicolumn{2}{|c|}{8 wk } \\
\hline & $\begin{array}{l}\text { Explant } \\
\text { weight }\end{array}$ & $\begin{array}{c}\text { Rhizome } \\
\text { length }\end{array}$ & $\begin{array}{c}\text { Explant } \\
\text { weight }\end{array}$ & $\begin{array}{c}\text { Rhizome } \\
\text { length }\end{array}$ & $\begin{array}{l}\text { Explant } \\
\text { weight }\end{array}$ & $\begin{array}{c}\text { Rhizome } \\
\text { length }\end{array}$ \\
\hline $\mathrm{g} \mathrm{L}^{-1}$ & g & $\mathrm{cm}$ & $\mathrm{g}$ & $\mathrm{cm}$ & $\mathrm{g}$ & $\mathrm{cm}$ \\
\hline 0.0 & $1.08 \mathrm{a}$ & $0.98 \mathrm{a}$ & $2.34 \mathrm{~b}$ & $1.82 \mathrm{a}$ & $3.01 \mathrm{~b}$ & $1.91 \mathrm{a}$ \\
\hline 3.5 & $1.06 \mathrm{a}$ & $1.07 \mathrm{a}$ & $2.81 \mathrm{a}$ & $1.73 \mathrm{a}$ & $3.79 \mathrm{a}$ & $1.77 \mathrm{a}$ \\
\hline 7.0 & $1.21 \mathrm{a}$ & $1.21 \mathrm{a}$ & $2.13 b$ & $1.54 \mathrm{a}$ & $2.99 \mathrm{~b}$ & $1.95 \mathrm{a}$ \\
\hline
\end{tabular}

Table 2. Explant weight and rhizome length observed after 0, 4 and $8 \mathrm{wk}$ on Alstroemeria pallida rhizomes cultured in vitro under four different 6-benzylaminopurine (BAP) concentrations.

\begin{tabular}{|c|c|c|c|c|c|c|}
\hline \multirow[b]{2}{*}{$\begin{array}{c}\text { BAP } \\
\text { concentration }\end{array}$} & \multicolumn{2}{|c|}{$0 \mathrm{wk}$} & \multicolumn{2}{|c|}{4 wk } & \multicolumn{2}{|c|}{$8 w k$} \\
\hline & $\begin{array}{l}\text { Explant } \\
\text { weight }\end{array}$ & $\begin{array}{l}\text { Rhizome } \\
\text { length }\end{array}$ & $\begin{array}{l}\text { Explant } \\
\text { weight }\end{array}$ & $\begin{array}{c}\text { Rhizome } \\
\text { length }\end{array}$ & $\begin{array}{l}\text { Explant } \\
\text { weight }\end{array}$ & $\begin{array}{c}\text { Rhizome } \\
\text { length }\end{array}$ \\
\hline $\mathrm{mg} \mathrm{L}^{-1}$ & $\mathrm{~g}$ & $\mathrm{~cm}$ & g & $\mathrm{cm}$ & $\mathrm{g}$ & $\mathrm{cm}$ \\
\hline 0.0 & $1.06 \mathrm{a}$ & $1.04 \mathrm{a}$ & $2.10 \mathrm{~b}$ & $1.57 \mathrm{a}$ & $2.40 \mathrm{~b}$ & $1.70 \mathrm{~b}$ \\
\hline 0.5 & $1.11 \mathrm{a}$ & $1.10 \mathrm{a}$ & $2.36 \mathrm{ab}$ & $1.57 \mathrm{a}$ & $2.92 \mathrm{~b}$ & $1.82 \mathrm{~b}$ \\
\hline 1.0 & $1.05 \mathrm{a}$ & $1.01 \mathrm{a}$ & $2.61 \mathrm{a}$ & $1.81 \mathrm{a}$ & $3.14 \mathrm{~b}$ & $2.18 \mathrm{a}$ \\
\hline 2.0 & $1.26 \mathrm{a}$ & $1.18 \mathrm{a}$ & $2.64 \mathrm{a}$ & $1.84 \mathrm{a}$ & $4.59 \mathrm{a}$ & $2.40 \mathrm{a}$ \\
\hline
\end{tabular}




\section{Effect of BAP and agar on explant development}

Proliferation rate and shoot length were evaluated after 4 and $8 \mathrm{wk}$ and the statistical analysis showed interactions between the effects of agar and BAP. The proliferation rate of alstroemeria rhizomes rose with increasing BAP concentrations. Hence, rhizomes grown in culture medium without BAP showed the lowest proliferation rate with values between 1.00 and 1.63 , whereas the highest proliferation rate was observed in rhizomes grown with $2.0 \mathrm{mg} \mathrm{L}^{-1} \mathrm{BAP}$, particularly in those rhizomes grown in culture medium supplemented with $2.0 \mathrm{mg} \mathrm{L}^{-1} \mathrm{BAP}$ and 3.5 $\mathrm{g} \cdot \mathrm{L}^{-1}$ agar, yielding 3.5 new explants after $8 \mathrm{wk}$ and showing significant differences to treatments using 0.0 and $0.5 \mathrm{mg} \mathrm{L}^{-1}$ BAP (Figure 1). Increasing concentrations of BAP promoted shorter shoots. Thus, rhizomes grown in culture medium without BAP and concentrations of 0.0 and $3.5 \mathrm{~g} \mathrm{~L}^{-1}$ showed the longest average shoots, 4.74 and $5.08 \mathrm{~cm}$ respectively, and significant differences with the rest of the treatments using BAP and both 0.0 and $7.0 \mathrm{~g} \mathrm{~L}^{-1}$ agar (Figure 1).

\section{DISCUSSION}

A lower agar concentration $\left(3.5 \mathrm{~g} \mathrm{~L}^{-1}\right)$ stimulated rhizome growth and weight gain probably because the explant was able to uptake water, BAP and nutrients more easily from the culture medium (Suthar et al., 2011). Moreover, agar concentration produces a dilution of exudates from explants and a more adequate aeration which may also stimulate rhizome growth (Ebrahim and Ibrahim, 2000). On the other hand, liquid medium $\left(0.0 \mathrm{~g} \mathrm{~L}^{-1}\right.$ agar $)$ may provoke hyperhydricity or vitrification and reduce growth and development of explants followed by translucence and eventually necrosis (Ebrahim, 2004). This symptom was
Figure 2. Development of Alstroemeria pallida in vitro rhizomes after 8 wk cultured under four different 6-benzylaminopurine (BAP) concentrations and three agar concentrations.

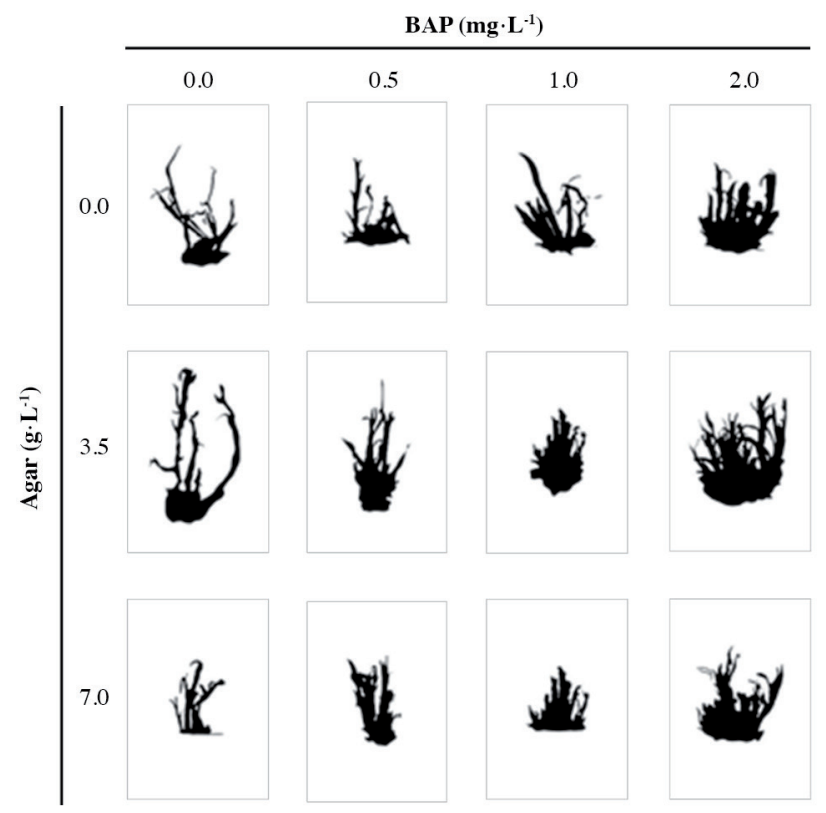

observed in some explants during this study, particularly in treatments using liquid culture media. Previous results have shown that supplementation with agar and Gelrite at 5 and $1.5 \mathrm{~g} \mathrm{~L}^{-1}$, respectively, showed the optimum results in terms of in vitro growth and development of both roots and shoots of Maranta leuconeura (Ebrahim and Ibrahim, 2000). Specifically for alstroemeria, liquid medium using a slow release of medium components has shown good results (de Klerk and ter Brugge, 2010), although most of the in vitro cultures of alstroemeria rhizomes have been conducted using gelling agents such as agar at concentrations between 7.0

Figure 1. Proliferation rate and shoot length observed after 8 wk on Alstroemeria pallida rhizomes cultured in vitro under four different 6-benzylaminopurine (BAP) concentrations and three agar concentrations.

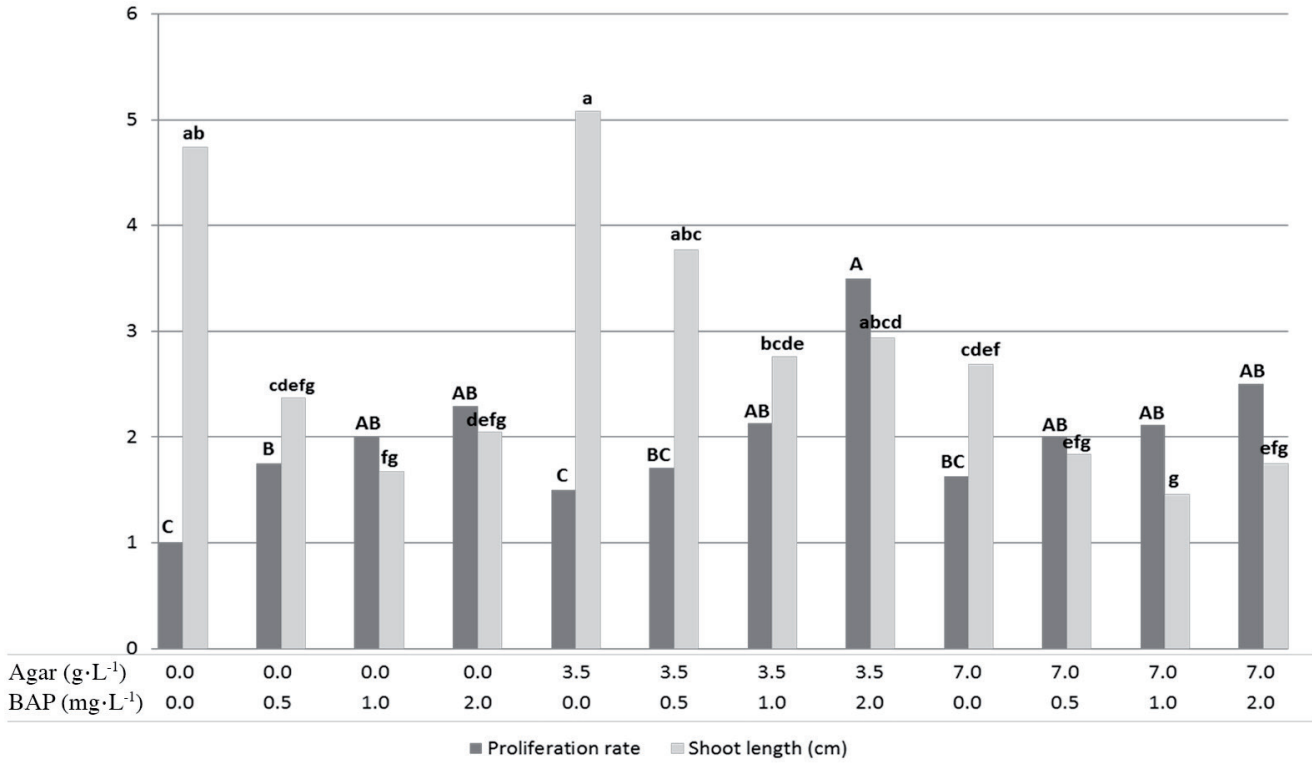


and $8.0 \mathrm{~g} \mathrm{~L}^{-1}$ (Seyyedyousefi et al., 2013; Hutchinson et al., 2014) and Gelrite at concentrations between $0.2 \%$ and $0.3 \%$ $(\mathrm{m} / \mathrm{v})$ (Hamidoghli et al., 2007; Pumisutapon et al., 2012).

Cytokinins are growth regulators with the ability to promote cell division and participate in important developmental roles such as shoot development (Moubayidin et al., 2009). For in vitro propagation of alstroemeria, BAP has been described as promoting the proliferation of rhizome shoots and growth (Khaleghi et al., 2008). These results agree with those obtained in the present study where rhizomes cultured in vitro showed greater development and proliferation of explants grown with media culture supplemented with $2.0 \mathrm{mg} \mathrm{L}^{-1}$ BAP whereas treatments using $0.0 \mathrm{mg} \mathrm{L}^{-1}$ BAP showed lower development and longer shoots. Moreover, the shorter shoots observed in rhizomes exposed to higher concentrations of BAP could be explained by the fact that cytokinins have been reported to reduce apical dominance (Ongaro and Leyser, 2008) (Figure 2).

BAP has been the most commonly used cytokinin for the micropropagation of alstroemeria rhizomes (Kyte et al., 2013), yielding better results than other cytokinins such as thidiazuron (1-phenyl-3-(1,2,3-thiadiazol-5-yl) urea; TDZ) (Pumisutapon et al., 2011; Shahriari et al., 2012) and 2ip ( $N$-(3-methylbut-2-enyl)-7H-purin-6amine; Shahriari et al., 2012).

\section{CONCLUSIONS}

An efficient method for the in vitro propagation of Alstroemeria pallida rhizomes has been described using MS supplemented with $3.5 \mathrm{~g} \mathrm{~L}^{-1}$ agar and $2.0 \mathrm{mg} \mathrm{L}^{-1}$ BAP. Considering the ornamental value of this native species, its conservation, domestication and further breeding could be supported by the methodology described in this study.

\section{ACKNOWLEDGEMENTS}

This work was supported by FONDECYT Initiation into Research $\mathrm{N}^{\mathrm{o}} 11130325$, Government of Chile.

\section{REFERENCES}

Aros, D., Valdés, S., Olate, E., and Infante, R. 2012. Gamma irradiation on Alstroemeria aurea $\mathrm{G}$. in vitro rhizomes: An approach to the appropriate dosage for breeding purposes. Revista de la Facultad de Ciencia Agrarias UNCuyo 44(1):191-197.

Bayer, E. 1987. Die gattung alstroemeria in Chile. Mitteilungen der Botanischen Staatssammlung München 24:79-83.

Bridgen, M., Kollman, E., and Lu, C. 2009. Interspecific hybridization of alstroemeria for the development of new ornamental plants. Acta Horticulturae 836:73-78.

Cavieres, L., Peñaloza, A., y Arroyo, M. 1998. Efectos del tamaño floral y densidad de flores en la visita de insectos polinizadores en Alstroemeria pallida Graham. Gayana Botanica 55(1):1-10.

Cruz, I., Angarita, A., and Mosquera, T. 2003. Induction of somatic embryogenesis in Alstroemeria spp. Agronomía Colombiana 21(3):121-128. de Klerk, G.J., and ter Brugge, J. 2010. Micropropagation of Alstroemeria in liquid medium using slow release of medium components. Propagation of Ornamental Plants 10(4):246-252.

Ebrahim, M. 2004. Comparison, determination and optimizing the conditions required for rhizome and shoot formation, and flowering of in vitro cultured calla explants. Scientia Horticulturae 101:305-313.

Ebrahim, M., and Ibrahim, I. 2000. Influence of medium solidification and $\mathrm{pH}$ value on in vitro propagation of Maranta leuconeura cv. Kerchoviana. Scientia Horticulturae 86:211-221.

Hamidoghli, Y., Bohloli, S., and Hatamzadeh, A. 2007. In vitro propagation of Alstroemeria using rhizome explants derived in vitro and in pot plants. African Journal of Biotechnology 6(18):2147-2149.

Hofreiter, A., and Rodríguez, E. 2006. The Alstroemeriaceae in Peru and neighbouring areas. Revista Peruana de Biología 13(1):5-69.

Hoshino, Y. 2008. Advances in alstroemeria biotechnology. p. 540-547. In da Silva, J. (ed.) Floriculture, ornamental and plant biotechnology. Advances and Topical Issues Vol. 5. Chapter 51. Global Science Books, Ikenobe, Japan.

Hutchinson, M.J., Onamu, R., Kipkosgei, L., and Obukosia, S.D. 2014. Effect of thidiazuron, NAA and BAP on in vitro propagation of Alstroemeria aurantiaca cv. 'Rosita' from shoot tip explants. The Journal of Agriculture, Science and Technology 12(2):60-69.

Khaleghi, A., Khalighi, A., and Sahraroo, A. 2008. In vitro propagation of Alstroemeria cv. 'Fuego'. American-Eurasian Journal of Agricultural and Environmental Sciences 3(3):492-497.

Kim, J.B., Raemakers, C.J., Jacobsen, E., and Visser, R.G.F. 2006. Efficient somatic embryogenesis in Alstroemeria. Plant Cell, Tissue and Organ Culture 86(2):233-238.

Kyte, L., Kleyn, J., Scoggins, H., and Bridgen, M. 2013. Plants from tubes: an introduction to micropropagation. $4^{\text {th }}$ ed. 269 p. Timber Press, Portland, Oregon, USA.

Lin, H.S., De Jeu, M.J., and Jacobsen, E. 1997. Direct shoot regeneration from excised leaf explants of in vitro grown seedlings of Alstroemeria L. Plant Cell Reports 16:770-774.

Lu, C., and Bridgen, M. 1997. Chromosome doubling and fertility study of Alstroemeria aurea $\times$ A. caryophyllaea. Euphytica 94:75-81.

Moubayidin, L., Di Mambro, R., and Sabatini, S. 2009. Cytokininauxin crosstalk. Trends in Plant Science 14(10):557-562.

Muñoz, M., and Moreira, A. 2003. Alstroemerias de Chile. Taller La Era, Santiago, Chile.

Murashige, T., and Skoog, F. 1962. A revised medium for rapid growth and bioassays with tobacco tissue cultures. Physiologiae Plantarum 15:473-497.

Nasri, F., Mortaza, S.N., Ghaderi, N., and Javadi, T. 2013. Propagation in vitro of Alstroemeria ligtu hybrid through direct organogenesis from leaf base. Journal of Horticultural Research 21(2):23-30

Ongaro, V., and Leyser, O. 2008. Hormonal control of shoot branching. Journal of Experimental Botany 59(1):67-74.

Pedraza-Santos, M.E., López-Peralta, M.C., GonzálezHernández, V.A., Engleman-Clark, E.M., and Sánchez-García, P. 2006. In vitro regeneration of Alstroemeria cv. 'Yellow king' by direct organogenesis. Plant Cell, Tissue and Organ Culture 84:189-198.

Pumisutapon, P., Visser, R.G.F., and de Klerk, G.J. 2011. Hormonal control of the outgrowth of axillary buds in Alstroemeria cultured in vitro. Biologia Plantarum 55(4):664-668. 
Pumisutapon, P., Visser, R.G.F., and de Klerk, G.J. 2012. Moderate abiotic stresses increase rhizome growth and outgrowth of axillary buds in Alstroemeria cultured in vitro. Plant Cell, Tissue and Organ Culture 110(3):395-400.

Seyyedyousefi, S.R., Kaviani, B., and Dehkaei, N.P. 2013. The effect of different concentrations of NAA and BAP on micropropagation of alstroemeria. European Journal of Experimental Biology 3(5):133-136.

Shahriari, A.G., Bagheri, A., Sharifi, A., and Moshtaghi, N. 2012. Efficient regeneration of 'Caralis' Alstroemeria cultivar from rhizome explants. Notulae Scientia Biologicae 4(2):86-90.
Suthar, R., Habibi, N., and Purohit, S. 2011. Influence of agar concentration and liquid medium on in vitro propagation of Boswellia serrata Roxb. Indian Journal of Biotechnology 10:224-227.

Van Zaayen, A. 1995. Alstroemeria. p. 340-343. In Loebenstein, G., Lawson, R.H., and Brunt, A.A. (eds.) Virus and virus-like diseases of bulb and flower crops. Wiley, West Sussex, UK.

Yousef, H., Sahar, B., and Abdollah, H. 2007. In vitro propagation of alstroemeria using rhizome explants derived in vitro and in pot plants. African Journal of Biotechnology 6(18):2147-2149. 